\title{
The Event in Migrant Categorization: Exploring Eventfulness Across the Americas
}

\author{
Heike Drotbohm' \\ Nanneke Winters ${ }^{12}$ \\ 'Department of Anthropology and African Studies, Johannes Gutenberg University Mainz, Germany \\ ${ }^{2}$ International Institute of Social Studies, Erasmus University Rotterdam, Netherlands
}

\begin{abstract}
The categories that define people on the move must be understood as unstable, contingent, and provisional processes. This paper contributes to a growing body of scholarship that explores the lived complexities of migrant categorization and their social implications. Based on fieldwork in Brazil and Central America, the paper investigates the processual character of categorization by intertwining temporal and spatial dimensions, focusing on specific events to understand the occasions, circumstances, and intentions that bring about adapted or entirely new categories. An eventful notion of categorization demonstrates not only how categories come into being but also how categories remain connected to particular events that are recognized or produced in response to movement. These categories stick to the identity of a subject in transit, confirming and solidifying it; however, they can also challenge the subject's legal stability, generating new insecurities and (im-)mobilities.
\end{abstract} Key words: Event; crisis; migrant categories; trans-American trajectories; Brazil; Central America. 


\section{O evento na categorização de migrantes: Explorando questões de "eventfulness" nas Américas}

\section{Resumo}

As categorias que definem as pessoas em movimento devem ser entendidas como processos instáveis, contingentes e provisórios. Este artigo contribui para um crescente corpo de estudos que explora as complexidades vividas da categorização de migrantes e suas implicações sociais. Baseado em trabalho de campo no Brasil e na América Central, o artigo investiga o caráter processual da categorização por meio do entrelaçamento das dimensões temporais e espaciais, focalizando eventos específicos para compreender as ocasiões, circunstâncias e intenções que geram categorias adaptadas ou inteiramente novas. Uma noção de categorização que inclui o significado de eventos particulares demonstra não apenas como as categorias surgem, mas também como as categorias permanecem conectadas a eventos particulares que são reconhecidos ou produzidos em resposta ao movimento. Essas categorias aderem à identidade de um sujeito em trânsito, confirmando-a e solidificando-a. No entanto, também podem abalar a estabilidade jurídica do sujeito, gerando novas inseguranças e (im) mobilidades.

Palavras-chave: Evento; crise; categorias de migrantes; trajetórias transamericanas; Brasil; América Central. 


\title{
The Event in Migrant Categorization: Exploring Eventfulness Across the Americas
}

\author{
Heike Drotbohm
}

Nanneke Winters

\section{Introduction}

\begin{abstract}
"Nos perdonan porque venimos caminando" - "They forgive us because we come walking." (Middle-aged Haitian man awaiting permission to move through Honduras despite his irregular entry into the country, January 2020).

"I never imagined myself 'a refugee.' Refugees - that was those people living on the hills; in large camps consisting of blue tents. When I came to Brazil, I learned that being a refugee can be something important, something to achieve. Here, I am a solicitante [asylum seeker]. And a solicitante from the Congo is different from one coming from Syria. Or Benin. And being a single mother with children also changes the situation, when you meet a lawyer or someone at the Conare [The National Committee for Refugees]." (Congolese woman, interviewed at the Centro de Referência para Refugiados, Caritas Arquidiocesana de São Paulo, March 2016).
\end{abstract}

The categories that define people on the move and shape their lives cannot be seen as neutral policy instruments. Categorization is an ongoing discursive and material process that hinges on both ongoing developments at the global level and the particularities and priorities of the localities of category interpretation and enactment. Across different settings, the cultural connotations and practical implications of categories such as migrant, refugee, and citizen change. Although such categories are characterized by a time- and place-based specificity, they are not isolated from broader circumstances but are instead intertwined with the political and moral framings shaped by various contexts. This double contingency destabilizes categories and the experience of categorization.

The Haitian man and the Congolese woman quoted here shared stories of displacement, traveling, and establishing oneself that describe these contingencies and the instability of categories. The ways they provoke, experience, and evaluate categories derive from the sense of exceptionality and urgency engendered by their presence. They are part of a larger collective of mobilized and immobilized Caribbean, African, and Asian nationals that have recently received substantial attention across Latin America. Not only migration scholars, but also humanitarian and faith-based organizations, tend to consider the phenomenon unprecedented and assume those lived experiences to have been irregular, dangerous, and full of suffering. Furthermore, governments, as well as policymakers and state agents, have responded to these emerging trans-American trajectories by creating and adapting categories for controlling and managing these traveling subjects.

Based on fieldwork in Brazil and Central America ${ }^{1}$, this paper investigates the processual character of categorization by intertwining temporal and spatial dimensions. It focuses on specific events in order to understand the occasions, circumstances, and intentions that produce new or adapted categories. By exploring how categories shift and change through events, we build on and extend the migration scholarship that has

\footnotetext{
This paper is based on the results of two different research projects, both generously funded by the German Research Foundation (DFG): DR 738/7-1 and DR 738/9-1. We take the occasion to also express our appreciation for the critical reading of this article provided by two anonymous reviewers of Vibrant - Virtual Brazilian Anthropology, for the organizers and participants of the "Dynamics of differentiation" panel at the DGSKA Conference 2019 in Konstanz, and for the research participants and institutions who welcomed us in the field.
} 
questioned the neutrality, stability, and encapsulating power of categorization (Crawley and Skleparis 2017; Mountz 2011; Robertson 2019). Through this process, we interrogate how events might provide a useful lens for pinpointing the temporal and spatial processes that trigger, displace, and alter categorization.

In what follows, we introduce an event-focused perspective on categorization by linking scholarship on events with recent thinking on migration-related categories. Then, we survey the increasingly diverse migratory context of our research and introduce our case studies. We examine the emergence and experience of the visto humanitario in Brazil, the flujo controlado in Panama and Costa Rica, and the permiso de ingreso y tránsito in Costa Rica by exploring the eventfulness of these categorizations and their social implications. We problematize the exceptional foundations of these categorizations, which offer temporary respite that might be negated by specific limitations and vulnerabilities. We conclude by highlighting the value of an event-focused perspective for understanding the contingent and changing yet sticky nature of the categories which continue to shape the lives of people trying to move on.

\section{Theoretical Framework: An Event-Focused Perspective on Categorization}

Social categories are ubiquitous and inevitable but also a conflictive element in modern societies (Hirschauer 2017), defining but also dividing social entities and providing as well as rejecting an individual's access to membership, belonging, and care. Migration scholars have explored the inclusive and exclusive dimensions of migration-related categories not only to interrogate the classic citizen-migrant dichotomy but also to understand the various immigration-status configurations - or "figures of membership" (Gonzales and Sigona 2017) - which intersect with other markers of social difference (Robertson 2019) and define the prerequisites for political, economic, and social inclusion (Bosniak 2006; Scheel and Squire 2014; Zetter 2007). Moreover, they have identified incompatibilities between pre-defined migration categories and the lived experiences of people displaced or otherwise on the move (Bakewell 2008; Crawley and Skleparis 2017). For example, scholars increasingly question an oversimplified binary conventionally drawn between migrants and refugees by demonstrating that motivations, strategies, brokers, routes, and travel communities vary and change over time, resulting in "mixed migration" (Van Hear 2009). A person's assigned migration category can change during both biographical and spatial processes.

Additionally, scholars have observed that migration categories are unstable because their legal frameworks are constantly changing at national and international levels (Squire 2011; Long 2013). This can have life-changing consequences for migrants; living transnationally, they might watch their border-crossing become problematic, or their residence status becomes threatened by new conditions. The work of Susan Coutin $(1998 ; 2000)$ on Salvadoran migrants' decades-long battle for permanent legal residency in the US serves as an example. By focusing on the changing political conditions in the country of origin as well as the relations between $\mathrm{El}$ Salvador and the US, she illuminates the plight of civil war refugees, who entered the country as "immigrants" in the early 1980 and then, beginning in 1986, became undocumented or "illegal workers," according to new restrictions imposed by the Immigration Reform and Control Act. Later, civil society actors intervened to direct the Salvadorans to apply for asylum. Coutin's ethnographic approach elaborates the set of practices that constitutes individuals as legal subjects within migration categories, given that immigration law has been made pertinent to an increasing number of contexts outside of formal legal settings, including seeking medical care, opening a bank account, soliciting employment, and applying for college (Coutin 200o).

Beyond the instability of migration categories, the numerous variants of "temporary protection status" present their own challenge; these labels have been standardized within the contemporary global migration regime, especially in the context of access to asylum or permanent residency (Squire 2011). Against this background, Thomaz (2018) interprets the proliferation of temporary protection statuses as a new boundary 
practice that restricts access to asylum and hollows out regular forms of entry, migrant rights, and government responsibilities. Building on Zetter (2007), who has problematized the increasing fragmentation of the refugee label, Thomaz draws attention to "the creation of new limits, novel legal categories that allow for entrance and permanence but under provisional terms." (2018: 207) Although such restrictive categories are considered undesirable and destabilizing, they are often based on humanitarian grounds; signifying compassion but not rights, they are a means of avoiding addressing the political contexts in which inequalities and disasters thrive. Thus, the new categories become a way of depoliticizing migrants' claims.

This paper furthers the notion that migration-related categories do not exist in a vacuum. Instead, they have all been specifically created at critical junctures to articulate and institutionalize distinctions perceived as opportune or necessary in given social or political contexts. Categories are dynamic and changing: when old ones no longer fit evolving needs, new ones are crafted to sort new realities appropriately. Furthermore, such categories can change according to the immediate context, coming into being under certain conditions in a specific locality, region, or institutional setting. Even categories with the same name can mean different things in different places, while simultaneously traveling and connecting areas across distances.

To manage this complexity, we investigate the processual character of categorization by intertwining temporal and spatial dimensions. We suggest focusing on events to understand the occasions, circumstances, and intentions for which existing categories are adapted and new ones created. The social sciences have renewed attention on events as a useful solution to the limitations of a field of study often conceived spatially or through social ties (Kapferer 2015). Different from ceremonial and ritual events, i.e. planned occasions that are often examined in the so-called Manchester tradition (Geertz 1973; Turner 1969), we concentrate on "critical events" (Das 1995) or "diagnostic events" (Moore 1987; Borneman and Ghassem-Fachandi 2017), understood as ruptures that bring something new into the world.

To understand the dynamic between mobile subjects, governing bodies, mechanisms of control, and the moral discourses attached to them, we approach the role of events in two interrelated ways. First, we focus on activities that produce or require movement and result in (the adaptation or creation of) categories; for example, a classic humanitarian crisis, such as a political conflict urging people to flee, which provokes a reconsideration of the il/legitimacy of migration. If events are framed as politically and ethically challenging - through specific media coverage, for instance - governments are required to demonstrate responsiveness and adapt their migration categories and policies. For example, certain critical events accompanying 2015's long summer of migration prompted temporary and selective openings of some European borders and resulted in temporary residence being granted to some (Borneman and Ghassem-Fachandi 2017; Holmes and Castañeda 2016). Other events with a particular function in the making of humanitarian or pro-migrant categories are disasters like earthquakes or pandemics (Rytter 2015; Fassin 2012).

Second, independent of environmental, political, or other "crises" that induce migration, the specific characteristics of people on the move can also produce an event frame and shifting of categories. When arrivals and gatherings of gendered and racialized subjects-in-transit in border zones receive public attention for being unusual, irregular, or even conspicuous, they may acquire the dimension of an event and become the object of particular modes of migration governance. For example, "boat people," first from Vietnam and later from Haiti and other countries, made specific migrations appear to be a state of emergency, prompting governments to readjust their immigration procedures. Furthermore, when mobile subjects make claims to certain rights, and for access to protection, their presence can be understood as a particular event, initiating a readjustment of categorization. Irrespective of their actual numbers, or the strength of their collective appearance, they become a target for divisive classification and other measures of control (Tazzioli 2020). 
Moreover, mobile subjects become an event triggering intervention precisely because they gather in certain places (ibid: 5,15 ), and not in others. Thus, a processual view of categorization through events should focus not only on a particular moment in time but also on the specific place. Furthermore, we argue that the emergence and experience of categories are not confined to a specific place; instead, this process exemplifies spatial connectivity. Following Veena Das (2007), we contend that the eventfulness of events is not limited by space and time, but extends in a processual manner, connecting places, people, and ways of thinking about the contemporary moment. In "Discourses of Displacement and Deservingness," Yarris and Castañeda (2015) demonstrate the significance of intersecting geopolitical interests and locally specific discourses about merit and agency, which complicate common migrant-refugee binaries yet still reinforce exclusionary categorizations. The ways governing bodies create and respond to migration events through categorization is thus closely related to both locally emplaced experiences with migration as well as with developments elsewhere. For example, in 2019, transit permits for African migrants in Mexico were revoked, a move closely related to the fraught history of Mexican and Central American migration to the US and the pressure from the US to change the terms of these migrations. Acknowledging the simultaneous importance of place and spatial connectivity further grounds our understanding of events and their role in the dynamic and interconnected processes of categorization.

Until now, scholarship has questioned migration-related categories (e.g., legal/illegal; migrant/refugee; temporary/permanent) by recognizing their often paradoxical nature (e.g., Mountz 2011), their changing discursive foundations (e.g., Yarris and Castañeda 2015) and the ways people on the move might move between these categories throughout non-linear journeys (e.g., Crawley and Skleparis 2017). We build on and extend this scholarship by exploring how eventfulness shifts and modulates categories based on fieldwork in Brazil and Central America, where categorizations beyond the migrant-refugee dichotomy have gained traction in the context of recent Caribbean, African, and Asian arrivals.

This work coincides with Robertson's (2019) description of status-making: "how migrant bodies are increasingly classified, quantified, coded and subsequently placed into hierarchies of categorization that are politically and socially determined and have embodied and material effects." (ibid.: 22o) However, our focus on eventfulness further interrogates the dynamic and relational process of categorization that Robertson recognizes. Drawing on emerging migrant categorization in Australia, Robertson convincingly demonstrates the production of statuses beyond static legal categories. She draws attention to the temporal and spatial underpinnings of categorization (that inform status), as in, for example, the case of "irregular maritime arrivals" (ibid.: 226). She also identifies specific events that are important for understanding categorization, such as migrant arrivals by boat and other moments framed as "scandals" (ibid.: 229). In this paper, we further interrogate the ways such events might provide a useful lens for identifying the temporal and spatial processes that trigger, displace, and alter categorization.

\section{Migration and Migrant Categorization Across the Americas}

Since the continent's early colonization, the Americas have been characterized by displacement, expulsion, and diverse dynamics of regional and cross-border migration. Although Latin America is far from a unified entity, for many of its countries, close social, economic, and political-legal entanglements require an approach that at once addresses individual political regimes and international migration politics and the volatility of human movement. In focusing on trans-American migration routes, we recognize that each locality and each individual state has its own shifting discourses, legal and bureaucratic regulations, and informal practices for dealing with diverse migrations (Cantor et al. 2015; Winters and Reiffen 2019). Thus, to understand how different 
migrant categories come into being, how distinct localities shape categorization along the way, and the kinds of experiences these categories generate, we suggest combining a transitory-subject-centered perspective that examines those (geo)political dynamics that impact the ways mobile populations are perceived, received, and categorized in moments of temporary presence.

In the last two decades, Latin America has become the scene of increased and increasingly diversified migration, both from within the region itself and from "extra-continental" African and Asian and "extraregional" Caribbean countries. Given much of this migration is partially irregular and transitory - thus challenging existing migration policy systems - countries in the region have tried to collaborate to manage the diversity of migrants and migrant statuses. Calls for collaboration often follow events framed as crises, which are faced by multiple countries and border communities simultaneously and generated by the geopolitical volatility that further illuminates the region's entanglements. For example, in 2015, opening up Ecuador's borders coincided with an imminent change in US-Cuba relations that spurred Cuban migration across the region and motivated Nicaragua to close its border, leaving migrants stuck in Costa Rica and Panama. To address these issues, various forums, conferences, and working groups have been organized in Central and South America by bodies such as the Regional Conference on Migration (also known as the Puebla Process), the Brazilian Conferência National Sobre Migrações e Refúgio (Comigrar), and the Organization of American States (OAS). In addition, the Latin American branches of international migrant and refugee organizations have published various topical reports (e.g., OAS/IOM 2016). These different meetings and reports mainly emphasize the regional exchange of information about migration flows, regional responses to these flows, and the importance of security and sovereignty as well as human rights. In turn, these discourses have influenced the local responses and emerging categories this paper analyzes.

As mentioned, we combine a temporal and spatial approach to understanding events that trigger, displace, and alter categorization processes. From a comparative perspective, we focus on governments reacting to events that are framed as "emergency," "security threat," and "special need," considering the impact of framing certain migrants as temporary, the intersection of national and regional borders and migration regimes, the characteristics of transit zones and the characterization of migrants as "out of place" and "moving through space." We follow the emergence of categories in specific premises and timeframes and examine the problems requiring intentional solutions for these new categories. Additionally, we examine the social implications of the newly emerged categories from the perspective of individuals. Although the empirical observations derive from two different research projects, it becomes clear that categorization dynamics in both Brazil and Central America are part of a trans-American migration constellation engendering cross-border control, containment, and movement.

We contrast two case studies from different research projects and field phases, both of which are characterized by a trajectory approach that follows people over time and through place. First, Heike Drotbohm has been working in São Paulo, Brazil since 2014, accompanying recent arrivals to the city on their trajectories through various forms of institutionalized care, such as those offered by humanitarian or faith-based organizations. The case of Haitian migrants, the focus here, was one of several that particularly illuminated the social consequences of categorization processes. Second, Nanneke Winters and Heike Drotbohm have been working together on a project examining trans-Atlantic and trans-American migrant trajectories in Central America since 2018. For this project, Nanneke conducted fieldwork in Costa Rica (August 2017 and April-May 2019), in Panama (February-March 2019), and in Honduras (January 2020). The fieldwork principally focused on Central American border zones and critical scenes of (in)formal reception and considered African, Cuban, and Haitian migrants, as well as local residents. In both Brazil and Central America, we worked with a flexible, situationally adapted methodology by visiting the spaces of encounter where migrants work, socialize, 
receive support, are controlled, and cross borders. As much as possible, we integrated ourselves into the everyday routines of these spaces, where we worked, observed, participated, and conducted interviews. Both authors use digital communication to maintain contact with a number of migrants.

\section{Adapting Categories to Emergencies: The visto humanitario in Brazil}

Disasters such as earthquakes, floods, and extreme droughts are typical crisis events that suddenly and unexpectedly set large groups of people in motion. Searching for protection, those forced to leave usually turn first to less affected places within their region; however, sometimes they look to other parts of the world, which may be considered promising due to existing personal contacts or international relations. This was the case after a major earthquake shook the island nation of Haiti in January 2010. Nearly 200,000 people were killed and 250,000 displaced within the country, with 1,130,000 remaining in makeshift camps indefinitely. As is often the case, the affected population's situation worsened after the actual catastrophe because the reconstruction work was poorly coordinated, and the population was exposed to new dangers, including depleted food security, malnutrition, and diseases.

Charles ${ }^{2}$, an approximately 50-year-old Haitian sugarcane cutter who had been living in the Dominican Republic since 2006, heard on the radio that Brazil had promised to provide special assistance to the Haitian people. We met for a coffee in São Paulo's city center in 2015, and I (Heike) asked him to explain his trajectory. He said, "Tranblemanntè souke nou tout" - the earthquake shook us all — referring to the mutual shock at the moment of the catastrophe. He recalled the Brazilian president Lula da Silva coming to Haiti a few days after the earthquake, where he promised solidarity to his friend, Haitian President René Préval.

As an "emerging power", Brazil had established a strong presence in Haiti before the earthquake, mainly through the engagement of the United Nations Stabilization Mission in Haiti (MINUSTAH), which had been under Brazilian leadership since 2004 (IOM 2014). As part of a "diplomacy of solidarity" (Aguilar 2012), this served to consolidate greater regional and international stability. Additionally, the government of Lula da Silva used humanitarian discourse to demonstrate a politics of "non-indifference" within South-South alliances. In Haiti, a country with widespread skepticism, bordering on cynicism, towards international interventions, Brazil intended to contradict top-down approaches by portraying itself as a reliable partner, or "the friendly hand connected to the strong arm" (Müller 2016).

Charles explained that he could have stayed in the Dominican Republic. But these were "tan boulvèse" troubled times - and many Haitians used the momentum to exchange conditions of exploitative labor and lived racism in Haiti's neighboring country for the hope of a "lavi miyò" - a better life. Brazil appeared to Charles to be a promising and realistic alternative to the US, which many Haitians no longer consider a dream destination due to its restrictive border policies and the racism Haitians often face. In January 2012, his idea to leave the country consolidated when he heard on the radio that Haitians were eligible to receive a special visa in Brazil.

This exemplifies how an event, even the apparently clearly defined crisis of an earthquake, can be eventful: the disaster extends not only in time, prompting many Haitians to leave their country even years after the earthquake itself, but also across space. While the central catastrophe occurred mainly in the metropolitan area of Port-au-Prince and the southern part of the island, it affected numerous individuals who would not perceive themselves as victims in the narrowly legalistic and spatially confined senses.

2 All personal names are pseudonyms. 
This special visa, which prompted thousands of Haitians to make their way to Brazil in 2012 and 2013, can only be understood by considering another event, which was also framed as a crisis. In the months immediately following the earthquake, numerous Haitians migrated to Brazil, where the Haitian presence was still small. In these months, a relatively liberal immigration policy made entry possible, but acquiring an official visa in Port-au-Prince's overcrowded Brazilian embassy was almost futile. ${ }^{3}$ For most Haitians, the path to Brazil was long: a plane to Colombia or Ecuador and then buses overland, often accompanied by costly and sometimes exploitative coyotes. The crucial moment occurred at Brazil's "green border," where travelers were obliged to contact federal police to document their border crossing. Due to the growing numbers overburdening this administrative procedure, transit nearly came to a halt. Thousands of Haitians waiting days and sometimes weeks in the small town of Brasiléia, in the state of Acre, created a camp-like situation; the related social and hygienic precariousness attracted substantial media attention. So many (primarily) Haitian migrants in this transit zone turned the Haitian condition, once more, into a crisis (Thomaz 2018).

The Brazilian authorities decided to facilitate the applications by treating Haitians as refugees and providing them with humanitarian aid. However, the category "environmental refugees" did not exist and, furthermore, it was agreed that it should not be created in order to avoid a precedent (Feldman-Bianco 2018). The provision of support to people who have been displaced by climate disruption poses a growing problem for governments and the UN (Merone and Tait 2018). In the case of Brasiléia, the decision process was transferred from the National Committee for Refugees (CONARE) to the National Immigration Council (CNig), a body linked to the ministry of labor. At a meeting in January 2012, this council decided to establish the visto humanitario (i.e. a humanitarian visa), which would be valid for 5 years and facilitate Haitian immigrants' social and economic integration into Brazilian society. An article published by the Migration Policy Institute describes Brazil's granting this type of visa as a successful move for the smooth administration of the approximately 98 , ooo Haitians that had arrived since the earthquake in 2010 (Weysa and Lesser 2018; Feldman-Bianco 2018).

\section{Experiencing Exceptionality and Permanent Transit in Brazil}

Charles reached São Paulo in 2012 when the country's construction industry was stimulated by an economic boom driven in part by preparations for the 2014 FIFA World Cup and the 2016 Summer Olympics (Gato and Salazar 2018). At this time, the formal conditions for Haitian immigration had been resolved, as we have explained. Charles crossed the border on the grounds of the visto humanitario and, after being transported to São Paulo, managed to obtain permanent residence status within a few months. He recalled how surprisingly uncomplicated the "paperwork" was, noting that Haitians were in a much better situation than both other migrants and asylum claimants, whose residence status remained protracted even after several months, or even years of maintaining constant contact with state or humanitarian organizations.

At the organizational level, the introduction of the pragmatic humanitarian approach can be called a success. However, the particularity of this temporary residence status and the resulting category of "humanitarian immigrant" has been criticized for distinguishing Haitians from other refugees who are eligible to claim asylum and, hence, the right to remain. Besides fractioning the refugee label, which depoliticizes Haitian migrants' claims to protection, Moulin and Thomaz argue that the Brazilian government had incorporated a form of control: the newly created status allowed Brazilian companies to employ Haitians in the unattractive, exploitative jobs that are usually rejected by Brazilian workers (Moulin and Thomaz 2016: 597):

\footnotetext{
3 We appreciate the comment of one of our reviewers, who clarified that the overcrowded situation at the Brazilian embassy in Port-au-Prince and reports of human rights violations on the land route made the National Immigration Council (CNIg) reconsider their entry regulations. The modification of the Resolução Normativa (RN) 102 26/04/2013 gave this visa a special character and permitted application at any Brazilian embassy, no longer limiting the application process to Haitians.
} 
[...] by naming Haitians as 'humanitarian immigrants', a specific regime of legality and (im)mobility was established - one that modulated Haitians in relation to the archetypical figure of refugees and migrant workers and that enabled a dual process of authorized permanence and precarious reception (Moulin and Thomaz 2016: 606).

Nonetheless, individual workers could see this regime not as increasing precarity but as increasing opportunities. After working on several construction sites for a few months and earning relatively well, Charles reactivated contact with relatives still living in Haiti by sending small remittances, thereby expressing commitment to his family. The Haiti-Brazil trajectory was established during this time, with several hundred Haitian migrants reaching São Paulo every week expecting hospitality, work, and a stable lifestyle. Rose, Charles' 22-year-old niece, was one of them. Before she received her visa at the Brazilian embassy in Port-auPrince and took the plane to Brazil, she and Charles hardly knew each other. The eldest daughter of one of Charles' sisters, Rose had grown up in Croix-des-Bouquets, close to Haiti's capital. Approximately one year after the earthquake, she managed to graduate from high school. Then, she started studying social work and working for an NGO in the field of technical reconstruction; later, on her mother's advice, she accepted her uncle's invitation to travel to Brazil. Rose and I met in March 2016 during job recruitment, which was regularly organized by a Catholic mission in the city center and which I was attending as a researcher. Job recruitment constituted meetings between employers looking for potential employees and migrants who had been invited to introduce themselves in brief job interviews, and Rose participated at least once a week.

During her first few months in São Paulo, Rose had to learn to accept failures. Given that she had enjoyed a relatively good education in Haiti, she had arrived in Brazil with high expectations: she was sure that she would be able to finish her studies and that her skills would be needed in Brazil. In the meantime, however, the Olympics and the World Cup were over, and Brazil had been hit by a deep political and economic crisis. The only job regularly offered to a young Haitian woman was work as a "faxineira" or "assistente de cozinha" - cleaning or cooking. Rose told me in frustration about the clichés she had to confront during interviews with potential employers.

Men find work as bricklayers or installers. When I describe my skills and say that I would like to work in administration, maybe as a secretary, I get a friendly smile. They are really friendly - I am not criticizing. But the problem is that they always want to help. They are looking for a "menina haitiana" — a girl from Haiti. They want to help me because I am a "pobrecito." An unfortunate creature. I can get a little work and a lot of pity, but not real employment. It's desperate. I sit here week after week and get into debt. I didn't study for that.

Although Rose reached Brazil a long time after the actual event, she remained tied to the category of suffering, which considerably limited her chances and choices. Although, like her uncle, she recognized the benefits provided by secure residence status, that status did not correspond to the general perception of Haitian migrants in Brazil. The unbearable and cumbersome categorization as victim stuck to Rose and, although she tried to move beyond this demarcated mode of existence and broaden her "imaginative horizon" (Crapanzano 2005), she had to recognize the improbability of realizing the original notions that had brought her to Brazil.

We met by chance, on the street, a few days later and she was in a hurry: finally, she had decided to leave Brazil for Argentina. She heard that there was a lot of employment, especially for those with better qualifications, and was sure that anything was better than the misery of life in Brazil. "Tu sais:je ne suis pas um refugiado" - I am not a refugee - she told me before we parted ways. This explicit rejection of the refugee category, which many asylum seekers consider to be so valuable and promising, recalled the Congolese woman quoted at the beginning of this article. It was striking to witness how much the value and relevance of a category had changed over time and space. 
Rose's story resonates the work of several authors who problematize the persistence of victimhood, which often prevails years and decades after an actual event or catastrophe, asking questions about when a crisis event ends and when ordinary life is possible, unencumbered by the category of victim. In the work of Martha Kumsa (2006), one interlocutor, a young Ethiopian refugee living in Canada, cried out, "No! I'm not a refugee!" She disidentified with the violence and pain that remained part of the category, which evoked the image of devastated individuals who were "fresh off the boat" (ibid.: 240). Some people, like Rose, decide to travel to another, more promising place; in her case, Argentina. Others continue further north, often with the idea of crossing Central America to eventually reach the US.

\section{New Approaches to Transit Migration in Costa Rica and Panama}

Haitians that decide to move further north join others currently traveling across Central America, including Cubans and Africans. ${ }^{4}$ Although these migrants are not new to the region, since 2015, their presence and visibility have increased due to geopolitical developments that have culminated in thousands of migrants getting stuck at different border crossing points for days, weeks, or even months. As mentioned previously, Cuban migrants who benefited from Ecuador's open migration policy before trying to travel to the United States via Colombia, Central America, and Mexico encountered a closed Nicaraguan border on their way north (Winters and Mora Izaguirre 2019). They were soon joined by Haitians who had left insecurity and political instability in Brazil (and, later, Chile and Venezuela) and by migrants from various African countries who had either traveled from Brazil or Argentina or recently arrived in the Americas via, mainly, Ecuador (Winters and Reiffen 2019). The growing presence of Africans in Latin America has been attributed, at least in part, to the increased difficulty of reaching Europe (Marcelino and Cerrutti 2011), a sentiment that is both tangible, due to new visa and asylum restrictions, and projected, a result of increasingly frequent and mediatized human catastrophes at sea and onshore (Sylla and Schultz 2020). In the Americas, Nicaragua closing the border to Haitians, Cubans, and Africans caused a chain reaction, increasing the visibility of those groups in countries further south. It prompted the Costa Rican government to temporarily close its border with Panama in early 2016, which, in turn, pushed the Panamanian government to temporarily block migrants who attempted to enter its territory from Colombia via the so-called Darién Gap. Along the three borders, migrants got stuck, which, as well as creating informal camps and sparking voluntary reception initiatives, generated social unrest.

The "sudden" appearance of what Tazzioli (2020) calls "migrant multiplicities" - temporary groupings of migrants that become a target for control and a source for claims-making — was framed as a "crisis" requiring a response. The problem was not that people on the move had not used this particular and mostly irregular route before; instead, it was that their presence had become more visible and increasingly marked them as a governmental concern due to a convergence of preceding and ongoing events. The eventfulness of this particular moment, at these particular borders, included a variety of elements: an earthquake, increasing insecurities and geopolitical changes in the Americas; changing asylum and migration procedures on the other side of the Atlantic; regional animosities and alliances. The moment also incorporated local developments in migration securitization, such as the breaking of a smuggling ring in northern Costa Rica (Winters and Mora Izaguirre 2019). Together, these elements shaped migrant perception and the use of this route, as well as instances of accumulation and blockage along certain borders.

The social identity of specific groups of migrants, in turn, further framed these accumulations and blockages as events. To indicate the situation's exceptionality, non-Latin-American migrants with black skin were commonly referred to as "extra-continental" migrants. The term was correct insofar as they had traveled to 
Central America from another continent; however, it accentuated the foreignness of these migrants. The term "extra-continental" refers not only to geographical location but also to a perceived social distance in terms of skin color, cultural background, and religious affiliation. Part of the visibilization and problematization of this interrupted migration was based on the perceptions of these migrants as different from the local population and the attendant assumptions, including those regarding standards of hygiene and health, food preparation and consumption, levels of poverty, and even terrorism (see Rivera 2018).

Central American governments were apparently overwhelmed by migrants they could not - despite their irregular entry - submit to the common tactic of deportation due not only to the extraordinary costs involved but also to the lack of diplomatic ties with many of the countries of origin. In recent years, several governments have moved from erratic to more coordinated responses to manage the situation. Some confronted the issue together and established new categories, informal policies, and humanitarian shelters as a result of factors such as the increased awareness of the limited possibility of stopping this type of migration, the exhaustion of local resources due to elevated numbers of asylum applications, the anxiety of local residents, and the limited alternatives for (temporary) regulation offered by existing migration policies. Temporary spaces of reception were set up along a "vertical" or "arterial border" (Vogt 2017) through the region.

In Costa Rica, a new migration document, the permiso de ingreso y tránsito (PIT - permit of entry and transit), was established for Cubans and then, beginning in 2016, for Haitians, Africans, and Asians. ${ }^{5}$ As documented by Winters and Mora Izaguirre (2019), the PIT guarantees access to police assistance, health care, and the country's two newly established migrant shelters, each individually known as a Centro de Atención Temporal a Migrantes (CATEM) - Center for Temporary Assistance to Migrants. The renewable permit provides both migrants and the state a relatively simple alternative to irregularity and mass asylum applications.

Additionally, in 2019 Costa Rica and Panama formally agreed to reinforce their flujo controlado policy. This flujo controlado - literally translated, "controlled flow" - is an institutionalized response designed to manage and secure what many border agents in the region consider to be an unstoppable migration from south to north. The response is based on the idea that virtually all migrants traveling this route wish to continue to North America and, thus, are closely monitored by the US. This fits in a long tradition of border externalization efforts, in which the US has attempted to control and deter certain types of immigration through agreements with Mexico and some Central American countries through force, diplomacy, and investment (Dominguez and Iñiguez Ramos 2016; Galemba 2013; Vogt 2017). Although Costa Rica, to the best of our knowledge, does not participate in any formal border externalization agreement with the US, it is entangled in regional migration management in myriad ways (see Winters and Mora Izaguirre 2019) and, just like Panama, shares information about migrants intending to cross its territory with the US. Notably, the flujo controlado appears to dissolve beyond Panama and Costa Rica, effectively leaving migrants to fend for themselves (and become irregular) for parts of their journey. ${ }^{6}$

The flujo controlado starts in Panama with the reception, evaluation, and containment of migrants emerging from the Darién Gap, or the "selva" (jungle). At the time of fieldwork, evaluation was mainly conducted in the newly installed Estación Temporal de Ayuda Humanitaria (ETAH - Temporary Station for Humanitarian Assistance), located in an indigenous community called La Peñita. It included registration of essential information such as age, sex, and nationality, sharing of biometric data with agencies such as Interpol, and a health check featuring several obligatory vaccinations. ${ }^{7}$ Migrants not appearing on any wanted list and deemed

\footnotetext{
5 As Cuban migrants generally travel with documents, the PIT takes the form of a sticker pasted at the back of their passports. For the others, the PIT is a one-page sheet with their basic information and a photo.

6 Although Honduras does not partake in the flujo controlado policy, the country shares registrations and biometrics of crossing migrants with the US. 7 In the case of minors, this evaluation also entails verifying relation to accompanying adults and, if necessary, the involvement of the Senniaf, the Panamanian department for families and children (or the PANI, its Costa Rican counterpart in one of the CATEMs).
} 
extra-regional or extra-continental as well as un-deportable, were classified according to nationality and order of entry before taking bus transport to another shelter in Panama's interior or to the western border-crossing point of Paso Canoas. Besides a vaccination card, they did not receive any documents that would prove they are part of this flujo controlado. In Paso Canoas, based on lists of names exchanged via the WhatsApp accounts of border and migration authorities on either side of the border, these migrants were transferred to Costa Rica, which would receive a fixed number of migrants on pre-established days of the week. Following a repeat of the biometric process, migrants could await the "visto bueno" (green light) at the CATEM near this border. Upon positive evaluation, they would be issued a PIT permitting travel across Costa Rica and, if desired, support, at the CATEM in La Cruz, before reaching the Nicaraguan border (see Drotbohm and Winters 2018; Winters and Reichl 2020).

The flujo controlado and the PIT serve to make these migrants legible, to register, evaluate and control them, to enable humanitarian support, and to ensure their swift move through these countries. Although they are not (yet) considered refugees, they are also not a "normal" group of migrants, who would be subject to, for example, detention or deportation because of their irregular entry and stay; that is, they have an exceptional status. Hence, the quasi-simultaneous rupture of migration orders, both regular and irregular, around the world, converged along specific border crossing points that became entangled in new categorizations.

\section{A Categorical Underpinning of Exceptional Uni-Directionality}

"No man enters the camp from town," said Harrison, from Cameroon, expressing frustration at his inability to access "the camp," the temporary humanitarian shelter in La Peñita that functions as the semi-formal starting point of the flujo controlado. He was denied entry because he had not emerged from the Darién Gap. His text and voice messages became increasingly desperate as he traveled up and down Panama attempting to become part of the movement towards Costa Rica.

In his early thirties, Harrison grew up on a farm in the English-speaking part of Cameroon. After earning an Agronomy degree, he started studying in Estonia; however, when he was ready for the next step in his career, he could not return to Cameroon due to re-intensified political turmoil and outbursts of violence (Pommerolle and De Marie Heungoup 2017). He decided to try his luck in the United States, getting on a flight to Ecuador. Although a Quito-based Cameroonian agent almost convinced him to pay for a welcome letter and additional documents to fly into Panama, Harrison discovered he could enter Panama with just his Schengen visa, which he did.

In mid-March 2019, we met at Panama City's central bus station, waiting for the bus to the western border, where I (Nanneke) noticed him because he was wearing a knitted hat more appropriate for a winter climate than the city's typical tropical humidity. When he asked the driver's assistant about the "frontier," I was convinced he was a migrant traveling north. Harrison sat next to me, and we spent most of the seven-hour bus ride talking about his background, migrations, and plans for the future. Although he seemed somewhat nervous about turning himself in to migration authorities upon reaching the border, he was also optimistic that they would allow him to cross with other migrants like him, and that he would meet up with other Cameroonians and accompany them north.

However, Harrison learned the hard way that migrants do not enter the flujo controlado from anywhere other than the Darién Gap. Stretching from the Pacific Ocean to the Caribbean Sea, the jungle area represents a crucial part of many migrants' journey north - not only because of the dangers it poses but also because of the shifting migration politics focused there. Despite the lack of a widespread state presence, the area has become pivotal in the enactment of territorial borders, national sovereignty, and international security interests. Although often depicted as tierra de nadie — no-man's land — the Darién Gap is inhabited by not only Panamanian border agents 
and indigenous communities but also paramilitary groups, guerrilla forces, drug smugglers, and wild animals, all of which have a role in this stretch of the migrants' journey overland from Colombia to Central America. In the past, while patrolling Darién, the military-equipped Panamanian border police Senafront would stop migrants and either send them back or let them pass. This decision typically depended on the geopolitical and national concerns and capacities of the particular moment, as well as the distance migrants were able to travel into Panamanian territory before being identified. Rather than disappearing, these considerations appear to have been streamlined by the flujo controlado policy. Migrants report that border agents generally allow them to continue to Puerto Obaldía, on the Caribbean side of the Darién Gap, or send them via various indigenous communities towards La Peñita, which is located on the interior close to the Pan-American highway. Migrants reportedly spend an average of two weeks traveling the Darién Gap.

The fact that Harrison did not travel across Darién (did not come through "the bush," in his words) eventually excluded him from the flujo controlado. At the border in Paso Canoas, migration officials told him he could not join the migrants that would be transferred to Costa Rica. Instead, he was directed to a migration office in David, a nearby city, where he was refused again, and advised to go back to Panama City to present his case to a refugee agency. Given that Harrison did not intend to ask for asylum, he instead traveled even further to present himself to agents at the border of the Darién province, hoping to get sent to La Peñita to go through the necessary process and take the bus like the other migrants. However, the border agents would not let him enter Darién. Finally, Harrison traveled back to the Costa Rican border again, crossed it illegally, and made it to the Costa Rican CATEM by himself.

The execution of the flujo controlado depends on the assumption, or even the requirement, of exceptional uni-directionality. If migrant journeys do not fit this mold, and the (imposed) suffering it implies, they are required to keep moving until they do. The Haitian man quoted at the beginning of this paper - "they forgive us because we come walking" - captures the sentiment that suffering the journey (in this case, walking through the jungle of Darién and other difficult stretches of Central America) appears to be an essential marker for control and eventual acceptance into a category allowing forward movement in spite of irregularity. Those who travel the Darién Gap and arrive on the Caribbean side are often sent back into the jungle to get to La Peñita. Migrants who make it to one of Senafront's bases in Darién are generally not taken to shelters elsewhere in Panama, nor returned to Colombia, but instead sent back into the jungle to find their way to La Peñita. They use information from migrants who have gone before them, paid assistance from local guides, and even directions from border agents, who know the dangers ahead, which include getting lost, assaulted, sick, or worse.

A migrant who illuminated this channeling aspect of the flujo controlado was Kwasi, a Ghanaian man in his early thirties who I met in the CATEM in La Cruz, northern Costa Rica. Kwasi was raised in the eastern region of Ghana and in Kumasi, Ghana's second city, where he also obtained his teacher's degree. A keen observer of his surroundings, Kwasi recounted his experience of traveling through Darién in detail. His accounts confirmed the practice of sending migrants through the jungle and reflected the formal and informal collaborations of border agents with the Darién residents that guide migrants through certain parts of their journey. Consider the following field notes from one of our first conversations:

They [Kwasi and his co-travelers] spent three weeks in Puerto Obaldia [Panama]. Then they started walking. The military drew them a map. On the first try, they got lost. They returned and the military told them they were crazy: "You need a guide: in the village, you can find one." You have to beg the military to recommend this. So, they go into town to look for a guide - the military knows about this. A big man took them at 11.30 for about two hours to Armila [another Senafront base]; they pitched their tent there, close to the mountains... The next morning the guides came back, and they walked for four hours... This time they found the entrance to the three mountains that the military had indicated. From here, they went by themselves. There were Panamanian flags on the trees indicating the route. You could see biscuits, cigarette bugs, soup. 
It was a rocky surface; your feet will be swollen... After the mountains, they arrived at the riverside, where they would find a man [according to Senafront]. They found four young guys sleeping and smoking under a roof of palm leaves. They charged them \$20 each for Canaan Membrillo [an indigenous community]; [it was supposedly] about 6 hours walking... But they were walking with strong men now, so, to [reach] Canaan, it only took them 4 hours. (Field notes from La Cruz, April 25, 2019).

In Canaan Membrillo, "the military" (the border agents) gave Kwasi and other members of his small group food; local residents rented them places to sleep. After a few days, Kwasi continued his journey to La Peñita, where he stayed for three weeks. The total journey from Panama's Colombian border to its Costa Rican border would take him more than a month.

Besides local strategies for directing migrants, the details of Kwasi's account demonstrate how this harrowing journey - which migrants wishing to travel north have to undertake - is differentiated. Old jungle paths are reinforced by passing migrants, but not all migrants pass in the same way. For example, Kwasi waiting weeks in the Puerto Obaldía community before deciding to walk through the jungle again resulted from an experience that he and his co-travelers perceived as racial discrimination by local authorities: apparently, certain groups of (non-African) migrants managed to get out of Puerto Obaldía around the same time via state-organized river or air transport. Meanwhile, Kwasi's comment that "they were walking with strong men now" referred to instances in which his group of young male co-travelers was slowed down by other migrants - in particular, families with children and pregnant women. Although these migrants may circle through the jungle in similar ways, they need more time, more food, and more guidance to become part of the flujo controlado.

The functioning of the flujo controlado resembles the attempted containment and channeling of migrants through forced movement described by Tazzioli (2020). The event-based categorization that underpins the flujo controlado (through a specific convergence of ruptured migration orders, foreign groups, and hostile terrain) assumes exceptional movement that must be controlled through exceptional uni-directionality. Nationality, ethnicity, race, gender, and other social markers differentiate this experience. The effects of this type of eventbased categorization include illegalization, as in the case of Harrison, and risks to health and life itself, as Kwasi experienced. At the same time, the flujo controlado presents migrants with an additional opportunity to move through the Americas that they would not have had otherwise if it were not for certain events. This interplay of the push and pull of categorization makes an eventfulness perspective illuminating. New categories and altered migration policies are triggered by the interconnected temporal and spatial processes of change in the Americas and across the Atlantic that culminate in "critical events" at specific border crossing points, while, at the same time, events are ongoing. Whereas in Brazil, the event-based categorization of Haitians as humanitarian immigrants complicates daily life and limits security, in Central America, new events may alter the experience of the flujo controlado.

\section{Concluding Discussion}

From a state perspective, categorization entails and enhances the capacity to count, monitor, and steer people on the move. For migrants, too, certain aspects of categorization can be beneficial: recognition, protection, and the organization of a continuing mobility, at least momentarily. The long history of categorization in the context of migration has made clear that temporary passports or visas often concern the continuity of travel rather than the integration into a given "host" society (Long 2013). The visto humanitario enables Haitians to remain in Brazil and to stabilize their lives - temporarily. Access to the flujo controlado in Panama and Costa Rica enables migrants to move further north, and access to the PIT in Costa Rica recognizes migrants' position 
and respects their fundamental rights. Migrants generally seem to benefit from this permit because it offers a certain level of protection on Costa Rican soil without blocking them from moving forward when they wish to do so.

However, neither the visto humanitario nor the flujo controlado or PIT offer sustainable legal avenues for claiming rights and lasting protection. Despite the sense of order that these newly created categories convey, they are based on responses to crises that may no longer correspond to the lives of migrants carving out a place for themselves or that may be too unstable for those still on the move. Haitians, who initially understood this newly emerging category as a welcome promise and an invitation to travel, found themselves, and their residence in Brazil, tied to the event. Although they developed new needs, demands, and identities over time, their stay in Brazil remained circumscribed by the original catastrophe. The moral framework that accompanied their original categorization as victims stuck to their evolving forms of belonging and determined their experiences long after the actual event. Both the apparent inescapability of events, especially in the moment of catastrophe, and the subsequent loosening of those ties must be problematized. When a certain category is eliminated or substituted, new dynamics of im/mobility can be initiated; a new category can not only confirm and solidify, but also complicate, legal stability.

This leads to more deeply probing the volatility of eventful categorization. The changing landscape of categorization implies a discretionary, insecure situation: migrants must always anticipate the possibility of future changes impacting their current condition and possibilities. They have to contemplate what is going to happen when new events occur, geopolitical interests and national concerns shift, and moral connotations change. They have to consider what happens if new migrant groups articulate other types of needs, which might be considered more urgent, and what happens if a new government is elected, signifying a new and possibly more restrictive regime of entry, presence, and transit. In Brazil, migrants, especially those with insecure residence status, are closely watching trends emerging from recent political tensions, which have culminated in the election of the ultra-right president Jair Bolsonaro. If the earlier promises of a liberal, prohumanitarian government are not kept, and support programs are gradually dismantled, once-promising categories may lose their validity. Rose, meanwhile, has already been living in Argentina for a while, where she had hoped to eventually stay.

It is also worth considering what happens if migrants traveling across the Americas find themselves blocked, illegalized, and without protection again. In February 2019, Panama's border with Colombia was suddenly closed; hundreds of migrants that had crossed part of the Darién Gap were halted in the jungle without any facilities. This closure followed multiple possible game changers, including a shipwreck the previous month, in which a group of migrants lost their lives in the waters between Colombia and Panama, the detection of malaria cases among migrants, and increased US vigilance given the turbulent situation in Venezuela. Such new events challenge previous event-based categorizations and access to protective categories and policies that have never been formally inscribed or regionally recognized, exemplifying the precarious nature of such categorizations.

The visto humanitario, the flujo controlado, and the PIT are delicately balanced between human movement and response to this movement, a balance that may shift, spurring migrants to find alternative routes. In this sense, an eventful notion of categorization shows how categories both move and morph. Categories may come into being due to particular events that are recognized or produced in response to movement. Categories also travel, to a certain extent, with migrants making their way through cities and across borders, revealing their opportunities and limitations along the way. Categories morph as they travel, from useful to relatively useless or powerless. Moreover, they morph as conditions around them develop; as times and contexts change, categories become either more pertinent or obsolete. The event-based character of these categories thus demonstrates how temporal and spatial processes trigger, displace, and alter categorization. 
A focus on the eventfulness of categories illuminates both the opportunities and limitations that ad-hoc categorization entails. Moreover, exploring the eventfulness of categorization productively demonstrates how new categories and policies are not just legal instruments but intersect other social markers, together producing a social meaning that "sticks" along the entirety of migrant trajectories. This paper has focused on the ways migrants experience and perceive the complex eventfulness of the categories that shape their lives. In reality, events bind together multiple actors. Future research on categorization would benefit from a simultaneous consideration of the perspectives of migrants, politicians, border agents, and humanitarian actors, among others; observing the ways they complement and contradict each other might thereby co-produce a more complex representation of the intricacies of lived categories.

Received: June 26, 2020

Approved: July 02, 2020

\section{References}

AGUILAR, Sérgio. 2012. "Emerging Powers, Humanitarian Assistance and Foreign Policy: the Case of Brazil during Earthquake Crisis in Haiti”. International Journal of Humanities and Social Science, 2(19): 93-101.

BAKEWELL, Oliver. 2008. "Research Beyond the Categories: The Importance of Policy Irrelevant Research into Forced Migration". Journal of Refugee Studies, 21(4): 432-453.

BORNEMAN, John; GHASSEM-FACHANDI, Parvis. 2017. "The Concept of Stimmung. From Indifference to Xenophobia in Germany's Refugee Crisis". Hau:Journal of Ethnographic Theory, 7(3): 105-135.

BOSNIAK, Linda. 2006. The Citizen and the Alien. Dilemmas of Contemporary Membership. Princeton: Princeton UP.

CANTOR, David J.; FREIER, Luisa F.; GAUCI, Jean-Pierre (org.). 2015. A Liberal Tide? Immigration and Asylum Law and Policy in Latin America. London: Institute of Latin American Studies, School of Advanced Study, University of London.

COUTIN, Susan B. 1998. "From Refugees to Immigrants: The Legalization Strategies of Salvadoran Immigrants and Activists". International Migration Review, 32(4): 901-925.

COUTIN, Susan B. 200o. Legalizing Moves. Salvadoran Immigrants' Struggle to US Residency. Ann Arbour: University of Michigan Press.

CRAPANZANO, Vincent. 2005. "Horizontes imaginativos e o aquém e além". Revista de Antropología, 48(1): 363-384.

CRAWLEY, Heaven; SKLEPARIS, Dimitris. 2017. "Refugees, Migrants, Neither, Both: Categorical Fetishism and the Politics of Bounding in Europe's 'Migration Crisis". Journal of Ethnic and Migration Studies, $44(1): 48-64$.

DAS, Veena. 1995. Critical Events: An Anthropological Perspective on Contemporary India. Oxford: Oxford University Press.

DAS, Veena. 2007. Life and Words: Violence and the Descent into the Ordinary. Berkeley and Los Angeles: University of California Press. 
DOMINGUEZ, R.; INIIGUEZ RAMOS, M. 2016. "The South/North axis of Border Management in Mexico". In: R. Zaiotti (org.), Externalizing Migration Management. Europe, North America and the Spread of "Remote Control" Practices. London: Routledge. pp. 225-237.

DROTBOHM, Heike; WINTERS, Nanneke. 2018. "Transnational Lives en Route: African Trajectories of Displacement and Emplacement Across Central America”. Working papers 175, Department of Anthropology and African Studies, Johannes Gutenberg University Mainz.

FASSIN, Didier. 2012. The Empire of Trauma. An Inquiry into the Condition of Victimhood. Oxford: Princeton UP. FELDMAN-BIANCO, Bela. 2018. "O Brasil frente ao regime global de controle das migrações: Direitos humanos, securitização e violências". Travessia - Revista do Migrante, 83: 11-36.

GALEMBA, Rebecca B. 2013. "Illegality and Invisibility at Margins and Borders". PoLAR: Political and Legal Anthropology Review, 36(2): 274-285.

GATO, Luana Gama; SALAZAR, Noel B. 2018. "Constructing a City, Building a Life: Brazilian Construction Workers' Continuous Mobility as a Permanent Life Strategy”. Mobilities, 13(5): 733-745. DOI: 10.1080/17450101.2018.1466504

GEERTZ, Clifford. 1973. "Deep Play: Notes on the Balinese Cockfight”. In: C. Geertz (org.) The Interpretation of Cultures. Selected Essays. New York: Basic Books 412-453.

GONZALES, Roberto; SIGONA, Nando. 2017. "Mapping the Soft Borders of Citizenship: An Introduction".

In: R. Gonzales; N. Sigona (orgs.), Within and Beyond citizenship. Borders, Membership, Belonging. London/ NYC: Routledge. pp. 1-16.

HIRSCHAUER, Stefan (org.). 2017. Un/doing Differences. Praktiken der Humandifferenzierung. Weilerswist: Velbrück Wissenschaft.

HOLMES, Seth; CASTAÑEDA, Heide. 2016. "Representing the 'European Refugee Crisis' in Germany and Beyond: Deservingness and Difference, Life and Death". American Ethnologist, 43(1): 12-24.

INTERNATIONAL ORGANIZATION FOR MIGRATION. 2014. Haitian Migration to Brazil: Characteristics, Opportunities and Challenges. Migration Notebook No 6. Buenos Aires: IOM. https:|/publications.iom.int/ system/files/pdf/cuaderno_migratorio_no6_en.pdf

KAPFERER, Bruce. 2015. "Introduction. In the event. Toward an Anthropology of Generic Moments". In L. Meinert; Bruce Kapferer (orgs.), In the event: toward an anthropology of generic moments. New York/ Oxford: Berghahn. pp. 1-29.

KUMSA, Martha K. 2006. “'No! I'm Not a Refugee!' The Poetics of Be-Longing among Young Oromos in Toronto". Journal of Refugee Studies, 19(2): 230-255.

LONG, Katy. 2013. "When Refugees Stopped Being Migrants: Movement, Labour and Humanitarian Protection". Migration Studies, 1(1): 4-26.

MARCELINO, Pedro F.; CERRUTTI, Marcela. 2011. Recent African Immigration to South America: The Cases of Argentina and Brasil in the Regional Context. Geneva: UN/ECLAC.

MERONE, Lea; TAIT, Peter. 2018. “'Climate refugees': Is it Time to Legally Acknowledge those Displaced by Climate Disruption?” Public Health, 42(6): 508-509.

MOORE, Sally F. 1987. "Explaining the Present: Theoretical Dilemmas in Processual Ethnography”. American Ethnologist, 14(4): 727-36.

MOULIN, Carolin; THOMAZ, Diana. 2016. “The Tactical Politics of 'Humanitarian' Immigration:

Negotiating Stasis, Enacting Mobility”. Citizenship Studies, (20)5: 595-609.

MOUNTZ, Alison. 2011. "Refugees - Performing Distinction: Paradoxical Positionings of the Displaced". In:

T. Cresswell; P. Merriman (orgs.), Geographies of Mobilities: Practices, Spaces, Subjects. London: Routledge.

pp. 255-269. 
MÜLLER, Markus M. 2016. “Entangled Pacifications: Peacekeeping, Counter-Insurgency and Policing in Port-au-Prince and Rio de Janeiro”. In: J. Hönke; M.M. Müller (orgs.), The Global Making of Policing. Postcolonial perspectives. New York: Routledge. pp 77-95.

OAS/IOM. 2016. Regional Report. Irregular Migration Flows to/within the Americas from Africa, Asia, and the Caribbean. Washington: General Secretariat of the Organization of American States and International Organization for Migration.

POMMEROLLE, Marie-Emmanuelle; DE MARIE HEUNGOUP, Hans. 2017. “Briefing. The 'Anglophone crisis': a Tale of the Cameroonian Postcolony". African Affairs, 116(464): 526-538.

RIVERA, Juan C. 2018. "Africanos que pasan por Honduras dejan ganancias millonarias a los coyotes". La Prensa. July 30, 2018. https:/|www.laprensa.hn/honduras/1202651-410/asiaticos-africanos-coyoteshonduras-migrantes-

ROBERTSON, Shanthi. 2019. "Status-Making: Rethinking Migrant Categorization”. Journal of Sociology, 55(2): 219-233.

RYTTER, Mikkel. 2015. "Events and Effects: Intensive Transnationalism Among Pakistanis in Denmark". In: L. Meinert; Bruce Kapferer (orgs.), In the event: toward an anthropology of generic moments. New York/ Oxford: Berghahn. pp. 90-106.

SCHEEL, Stephan; SQUIRE, Vicki. 2014. "Forced Migrants as Illegal Migrants". In: E. Fiddian-Qasmiyeh; G. Loescher; K. Long; N. Sigona (orgs.), The Oxford Handbook of Refugee and Forced Migration Studies. Oxford: Oxford University Press. pp. 188-199.

SQUIRE, Vicki. 2011. "The Contested Politics of Mobility: Politicizing Mobility, Mobilizing Politics". In: V.

Squire (org.), The Contested Politics of Mobility. Borderlines and Irregularity. London/ New York: Routledge. pp. 1-26.

SYLLA, Almamy; SCHULTZ, Susanne U. 2020. "Commemorating the Deadly Other Side of Externalized Borders Through 'Migrant-Martyrs', Sacrifices and Politizations of (Irregular) Migration on the International Migrants' Day in Mali”. Comparative Migration Studies, 8(4). https://doi.org/10.1186/s40878019-0167-x

TAZZIOLI, Martina. 2020. The Making of Migration. The Biopolitics of Mobility at Europe's Borders. London: Sage. THOMAZ, Diana. 2018. "What's in a Category? The Politics of Not Being a Refugee". Social and Legal Studies, $27(29): 200-218$.

TURNER, Victor. 1969. The Ritual Process. London: Routledge \& Kegan Paul.

VAN HEAR, Nicholas. 2009. "Managing mobility for human development: the growing salience of mixed migration". United Nations Development Programme, Human Development Reports Research Paper. New York: UNDP.

VOGT, Wendy A. 2017. “The Arterial Border: Negotiating Economies of Risk and Violence in Mexico's Security Regime". International Journal of Migration and Border Studies, 3(2/3): 192-207.

WEJSA, Shari; Jeffrey LESSER. 2018. Migration in Brazil: The Making of a Multicultural Society. Migrationpolicy.org, 23 Oct. 2019, www.migrationpolicy.org/article/migration-brazil-makingmulticultural-society.

WINTERS, Nanneke; MORA IZAGUIRRE, Cynthia. 2019. "Es Cosa Suya: Entanglements of Border Externalization and African Transit Migration in Northern Costa Rica". Comparative Migration Studies, 7(27). https://doi.org/10.1186/s40878-019-0131-9

WINTERS, Nanneke; REICHL, Elena. "Pay and go? Transit Migration Regimes and Migrant Navigation in Central America”. Border Criminologies Blog. April 9, 2020. https://www.law.ox.ac.uk/research-subjectgroups/centre-criminology/centreborder-criminologies/blog/2020/04/pay-and-go 
WINTERS, Nanneke; REIFFEN, Franziska. 2019. "Haciendo-Lugar vía Huellas y Apegos: Las Personas Migrantes Africanas y Sus Experiencias de Movilidad, Inmovilidad e Inserción Local en América Latina. Introducción al Dossier Temático REMHU 56". REMHU, Revista Interdisciplinar da Mobilidade Humana, 27(56): 11-33.

YARRIS, Kristin; CASTAÑEDA, Heide. 2015. "Discourses of Displacement and Deservingness: Interrogating Distinctions between 'Economic' and 'Forced' Migration. Introduction”. International Migration, 53(3): 64-69.

ZETTER, Roger. 2007. "More Labels, Fewer Refugees: Remaking the Refugee Label in an Era of Globalization”. Journal of Refugee Studies, 20(2): 172-192.

Heike Drotbohm

https://orcid.org/oooo-0002-9436-9137

Email:drotbohm@uni-mainz.de

Nanneke Winters

https://orcid.org/oooo-0002-8036-3690

Email:winters@iss.nl 